\title{
INCORPORATING ISLAMISM INTO SECULAR EDUCATION SYSTEM An Attempt of Gradual Islamization of the State and Society by an Indonesian Tarbiyah Movement in Jambi
}

\author{
Suaidi Asyari \\ UIN Sulthan Thaha Saifuddin, Jambi - Indonesia | sudi531@yahoo.co.uk
}

\begin{abstract}
The downfall of the New Order regime in 1998, which was soon followed by the liberalization policy in almost every aspect of politics, opened vast opportunities for the emergence of political expressions including Islamism into the public space. While violent responses indicated by some Islamic groups, who take advantage of the weakening of the state, Tarbiyah Movement (harakah tarbiyah) consistently performs gradual Islamization through the system provided by the state. Based on a field research in Jambi, Sumatra, this article discusses the efforts undertaken by the group to incorporate their Islamist ideas into secular education system at the levels of primary and secondary education. This article argues that these all efforts are part of Islamization process of society and the state in Indonesia after the failure of its leaders in doing the same thing at the political level especially in the aftermath of the 1999 general election.
\end{abstract}

Keywords: Tarbiyah movement, Islamization of the state, Islamic education, post-New Order Indonesia.

\footnotetext{
${ }^{1}$ The earlier draft of this paper was presented at the Oxford Symposium on Religious Studies at the Old Library of the University Church of St Mary the Virgin, Oxford, 1517 March 2017 with co-presenter Husnul Abid. I would like to thank Husnul Abid for his part in contributing to the earlier version of the paper. We would like to thank Canon Brian Mountford MBE, for having invited us to present the draft of this paper at the Oxford University and shared the findings of this research with scholars from various universities around the world, including the University of Melbourne, the University of Suffolk, UK, the University of Hong Kong China, University of Toronto Canada and California State University, USA to name a few. This study was supported by the Institute of Research and Community Service (LP2M) UIN Sulthan Thaha Saifuddin (STS) Jambi under the project "Religion-Based Social Movements" with contract number 1017/2016. In addition to LP2M, we thank the members of other researchers, namely Marwazi, Maisah, and Samsu.
} 
"What you want in the state, you must put into the school."

(Coleman in Azra, 1999: 61)

\section{Introduction}

Throughout the history of Indonesia, education is not an area that stands alone which is free from political factors. Rather, it has become boisterous area of contestation between various interest groups, including groups that claim themselves as "Islamic". In many ways even these groups have a crucial role in determining the direction of national education policy. ${ }^{2}$ In a country whose constitution is not based on a particular religion, something like this is relatively anomalous. In fact, since the Dutch colonial government intervened into Indonesia's education system by the end of the 19th century, there has been a dualistic mode of education system. On the one hand there is the so-called general education, where the state is trying to be "secular" and neutral from all religions. On the other hand, the state in which most of the population adheres to Islam has tried to accommodate the interests of Muslims through religious education. Not only by providing regulation, the state through the Ministry of Religious Affairs also supports Islamic education system in madrasah, the schools which are commonly run side by side with a general education system. Interestingly, there are two different and separate systems as well as working on their own, in its latest development, "the Islamic educational system ... has adapted and fit into the general education system."3

\footnotetext{
2 The most obvious example is the current legislative process of the two laws on the education, ie., Act No. 2 year 1989 National Education System which was later updated by Act No. 20 year 2003 about National Education System. For the first study on this, see for example Muhammad Sirozi, Politik Kebijakan Pendidikan di Indonesia: Peran Tokoh-tokoh Islam dalam Penyusunan UU No. 2/1989 (Leiden-Jakarta: INIS, 2004); Jusuf Amir Feisal, Reorientasi Pendidikan Islam (Jakarta: Gema Insani Press, 1995), particularly on the part of "Sumbangan Islam dalam Pembaruan Pendidikan Nasional", pp. 13126. As for the second note, see among others Benny Susetyo, Politik Pendidikan Penguasa (Yogyakarta: LKiS, 2005), particularly chapter 3: "Catatan Kritis atas UU Sisdiknas" and chapter 4: "Agama, Pendidikan, and Pendidikan Agama", pp. 41-106.

${ }^{3}$ Karel A. Steenbrink, Pesantren, Madrasah, Sekolab: Pendidikan Islam dalam Kurun Moderen (Jakarta: LP3ES, 1994), p. 7. For further details, see the book on the history of Islamic education in Indonesia since the colonial period. Compare with Mahmud Yunus, Sejarah Pendidikan Islam di Indonesia (Jakarta: Mutiara, 1979).
} 
At a time when restriction of the New Order, which had a policy of limiting the expression through political accommodation-including education - the implementation of both systems, coupled with pesantren system which was an educational institution of traditional Islam established much earlier, worked "appropriately". What is called "adjustment of Islamic education into the general education system", which later gave the birth to institutionalization of madrasah, ${ }^{4}$ is still inside the scope prescribed by the regime. Even if there were Islamic organizations or groups that wanted to incorporate their interests or ideology into the state educational system, certainly it did not disturb or destroy the existing system, because the organization and the group had basically been "domesticated", as part of the state accommodated institution. ${ }^{5}$

Various problems arose when the regime under Soeharto finally fell down in May 1998, preceded by the multidimensional crises that weakened the state's capacity to effectively control its citizens. This is in addition to the liberalization policy by his successors, the various expressions which were repressed and was under the ground then sprang up, including those of Islamist groups, which had certain political goals, and used education as a means of achieving that goal. In the post-New Order, several Islamic groups, for example, immediately reveals the radical characters and some of the students and alumni of certain institutions have engaged in terrorism-related acts. However, there are different groups that have been continuing to be consistent with the path of peace and gradual Islamization through a system provided by the state, for example by setting up a political party and participate in elections and to establish educational institutions. ${ }^{6}$ Among the groups is Tarbiyah Movement.

This article discusses the various efforts made by activists of Tarbiyah Movement (TM) in inserting their Islamic ideas into the state education system. During the New Order regime, this movement was more common in college campuses and engaged in missionary activity

\footnotetext{
${ }^{4}$ Maksum, Madrasab: Sejarah dan Perkembangannya (Jakarta: Logos, 1999). See also, Steenbrink, Pesantren, Madrasab; Yunus, Sejarah Pendidikan.

5 Afan Gaffar, "Politik Akomodasi: Islam dan Negara di Indonesia," in M. Imam Aziz (ed.), Agama, Demokrasi dan Keadilan (Jakarta: Gramedia Pustaka Utama, 1993).

${ }^{6}$ Julie Chernov Hwang, Peaceful Islamist Mobilization in the Muslim World: What Went Right (New York: Palgrave Macmillan, 2009), p. 75.
} 
by making smaller religious groups containing tens of students to study Islam together under the guidance of a mentor (murabbi or murabbiyab). Normalization policy of Campus Life/Campus Coordinating Board (NKK/BKK), which prohibited students to participate in practical politics, also contributes to the spread of the cells of this cultural movement in many universities in Indonesia. When the regime fell down in 1998, which was soon followed by state policy to be more open to political expression, including those from the Islamic Movement of Tarbiyah transformed into a political party, the Justice Party (PK) and later renamed the Prosperous Justice Party (PKS), then participated in elections. ${ }^{7}$ Although it has been included in the structural path to take part in practical politics to influence state policy, TM has never left or forgotten the propaganda lines at cultural level. In education, TM established many formal schools as the place they can implement their ideas concerning this field. ${ }^{8}$ At the same time, the Tarbiyah Movement also continues to do informal coaching to students in the form of small study groups in schools that are not theirs. ${ }^{9}$ Based on field research in Jambi, this article argues that the formal and informal educational path has been pursued by the TM in order to spread their Islamist idealism. The field of education has become the most important field in the effort of Islamizing the society and the state which is the ultimate goal of this movement.

To support these arguments, this article is divided into several sections. Following the introduction will be presented Tarbiyah Move-

\footnotetext{
7 Ali Said Damanik, Fenomena Partai Keadilan: Transformasi 20 Tabun Gerakan Tarbiyah di Indonesia (Jakarta: Teraju, 2001); Aay Muhammad Furkon, Partai Keadilan Sejabtera: Ideologi dan Praksis Politik Kaum Muda Muslim Indonesia Kontemporer (Jakarta: Teraju, 2004); Yon Machmudi, Partai Keadilan Sejabtera: Wajah Baru Islam Politik Indonesia (Bandung: Harakatuna Publishing, 2005); Yon Machmudi, Islamising Indonesia: The Rise of Jemaah Tarbiyah and the Prosperous Justice Party (PKS) (Canberra: ANU E Press, 2008); M. Imdadun Rahmat, Ideologi Politik PKS: Dari Masjid Kampus ke Gedung Parlemen (Yogyakarta: LKiS, 2008).

${ }^{8}$ Noorhaidi Hasan, "Islamizing Formal Education: Integrated Islamic School and a New Trend in Formal Education Institution in Indonesia," RSIS Working Paper, No. 172 (Singapore: Nanyang Technological University, 2009); Noorhaidi Hasan, "Education, Young Islamists and Integrated Islamic Schools in Indonesia," Studia Islamika, 19, 1 (2012), pp. 77-111.

${ }^{9}$ Hairus Salim, Najib Kailani, dan Nikmal Azekiyah, Politik Ruang Publik Sekolab: Negosiasi dan Resistensi di SMUN di Yogyakarta (Yogyakarta: CRCS, 2011).
} 
ment's historical background and its idealism in the field of education. The next section discusses the development of this movement in Jambi, followed by efforts that this movement has been working in education. Those efforts are primarily seen by the following classification: in primary and secondary education institutions owned, outside educational institutions belonging to MT, as well as in higher education institutions or universities. Before the closing section, efforts of TM are discussed further by associating it with the ideology and the main purpose of this movement.

\section{Tarbiyah Movement and Islamization through Education}

Indeed, Tarbiyah Movement has a very close relationship with the world of education. The name of this movement, which is derived from the Arabic tarbiyyah, literally means education. The word tarbiyyah also contains or can be formed from the word rabb, meaning God. Thus, tarbiyyah is not an educational activity or ordinary knowledge transfer in general, but it has "aspects of God or faith" to "form a man who is faithful to God." 10 For TM itself, the educational activity is the process to bring the community and the citizens of the world into salvation under the auspices of Islam. Hasan al-Banna, the founder of the Muslim Brotherhood in Egypt, whose ideas are the main inspiration of the movement, said that the ideals to be achieved in tarbiyyah are "the realization of a Muslim individuals, the Muslim family, and the Muslim community at large". ${ }^{11}$ In other words, tarbiyyah is equal to the activity of Islamization.

Although it has the ultimate goal of Islamization of society and even the state, the road that has been taken by the TM is a peaceful and gradual process, not revolutionary let alone using violence and coercion. As suggested by al-Banna, the process should start from individuals, family, then the community or nation and finally the world:

Improvements in the individual scale will take effect for the improvement of the family, because the family is a collection of individuals. If the family members of righteous men and women shali-

\footnotetext{
${ }^{10}$ Yusuf al-Qardhawy, Pendidikan Islam dan Madrasah Hasan al-Banna (Jakarta: np, 1980), p. 9.

${ }^{11}$ Hasan al-Banna, Himpunan Risalah, trant, (np), 394. This objective is also repeated in other texts such as Tarbiyah.
} 
bah -both are the pillars of family- then they will be able to build an ideal family, according to the benchmark that has been guided proportionally by Islam ... If a family has built up a righteous, the people will be salih, because umma is a collection of family. In other words, the real family is a miniature of the people, while the people are a large family. ${ }^{12}$

As a synonym of Islamization, education within the concept of Tarbiyah movement is applied in the three stages above. As the most basic stage which is the basis of Islamization of education, the individual level is obviously very important. At this level, education seeks to establish the individuals who are physically strong, good character, knowledgeable, creative and skilled in working, straight creed, diligent in worship, emotionally stable, disciplined, able to implement Islamic values, and beneficial to others. ${ }^{13}$ Such characters are needed not only for the individuals who are the components that make up the congregation, ${ }^{14}$ but also because these individuals will eventually establish a family and are responsible for educating family, which is the second stage in the Islamization. ${ }^{15}$

It could be said that the family is the most important concept in education within the Tarbiyah movement. In Arabic, the family is called usrah. This word is used by TM to call the "family" consisting of approximately ten of learners (mutarabbi/mutarabbiyab) led by an educator or mentor (murabbi/murabbiyah). They hold meetings (liqa') periodically, usually once a week, at places agreed upon, usually in the homes of members of usrah sequentially or generally in the mosque. In addition to knowledge transfer for Islamist thoughts or teachings, liqa' is also useful to foster a sense of kinship among members of usrah. This sense of kinship is regarded as particular importance. This can be understood from every liqa' which begins with sharing problems being faced by each member to be solved jointly, before getting into the ma-

\footnotetext{
12 al-Banna, Himpunan Risalah, pp. 392-393.

13 Ali Abdul Halim Mahmud, Ikhwanul Muslimin: Konsep Gerakan Terpadu, translated by Masykur Halim and Ubaidillah (Jakarta: Gema Insani Press, 1997), pp. 16-17.

14 al-Banna, Himpunan Risalah, p. 60.

15 About the importance of family in the Islamization movement of MT, see Suaidi Asyari and M. Husnul Abid, "Expanding Tarbiyah Movement Through Ta'aruf and Marriage," Al-Jämi'ab: Journal of Islamic Studies, Vol. 54, no. 2 (2016): pp. 337-368.
} 
terial of other Islamic ideological teachings which includes tabsin or reciting the Qur'an. This is followed by activities provided by $m u$ rabbi/murabbiyah, such as studying books that are considered important. Sense of family is strongly fostered through visits to sites together and staying one night at a mosque to perform worship or rituals together called MABIT (Malam Bina Iman dan Takwa, or night establishment of faith and piety). Pattern of tight togetherness in usrab in the making of the members of the movement is mutually reinforced and are committed, making a person who has entered into Tarbiyah very difficult to find a way out. Similarly, others from outside usrah are not easy to get access to the TM. As a result, from the outside, it looks very exclusive group and it is.

Generally speaking, there are a number of levels (marhalab) in Tarbiyah Movement. This is to indicate one's membership position within the movement namely tambidi (beginner or new member), muayyid (youth), muntasib (madya or junior), and muntazim (senior). ${ }^{16}$ In every level, usrah has its own curriculum which is fully supported with learning modules. This curriculum is delivered though liqa' or halaqah. ${ }^{17}$ Every member who has completed a study on one level, is sent up to the next upper level and so on. When a member has reached the level muntasib, he has not only become mutarabbi/mutarabbiyah or member of usrah at that level, but he is also obliged to recruit new members and manage them in a new usrah of the lower level, i.e. tambidi or muayyid. There he is then cast as a mentor or murabbi/murabbiyah for its members.

By using usrah system that resembles cell proliferation in the biological sense as well as multilevel marketing (MLM) system in marketing, TM grows very rapidly among students of general colleges in Indonesia. Such closed education system is able to penetrate even the restriction of the New Order against a variety of political expression, including those came from Islamic circles. Although Islamism wishes

16 Compare with Burhanuddin Muhtadi, Dilema PKS: Suara dan Syariab (Jakarta: Kepustakaan Populer Gramedia, 2012), pp. 149-150.

${ }^{17}$ See, for example the Writer Team for Module Lembaga Kajian Manhaj Tarbiyah (LKMT), Modul Tarbiyah Islamiyah untuk, Murobbi: Marbalab Tambidi, Vol. 1 and 2 (Jakarta: Robbani Press, n.d.); Writer Team for Module Lembaga Kajian Manhaj Tarbiyah (LKMT), Modul Tarbiyah Islamiyah untuk. Mutarabbi: Marbalab Tambidi, Vol. 1 and 2 (Jakarta: Robbani Press, n.d.). 
to create Indonesia an Islamic state had appeared before Independence, usrah was introduced after the coming of the New Order. Following the political deadlock since the New Order's prohibition of Masyumi to return to the path of struggle constitutionally, after the previous government of Sukarno dissolved this party on the pretext of engaging in the uprising of Revolutionary Government of the Republic of Indonesia/Struggle of the People of the Universe (PRRI/Permesta), its prominent leader, Mohammad Natsir, established the Indonesian Islamic Propagation Council (DDII) in 1967. Initially it was intended to prevent the massive conversion from Islam to Christianity and $\mathrm{Ca}$ tholicism in post-event $1965,{ }^{18}$ this organization was engaged in the cultural realm by working with institutions in the Middle East and targeting campuses as an important propaganda targets. In campus mosques like Salman mosque of the Bandung Institute of Technology (ITB), Arif Rahman Hakim at the University of Indonesia (UI) in Jakarta, and Salahudin at the University of Gadjah Mada (UGM) in Yogyakarta, propagation (dakwah) trainings were held for dakwah cadres who were prepared to spread their idea of islamism. A number of prominent cadres of propaganda alumnus were also sent to study in the Middle East during that time.

Indeed usrab is a non-formal educational institution of TM, which is very suitable to be applied at a time of pressure of authoritarian regime of the New Order. This pattern is useful for making members to mutually watch one another, keep secrets together and foster mutual commitment, as a family (usrab). In the midst of the pressures and restrictions on the movement of expression, underground movement pattern is considered to be the best way to scroll through a gradual process of Islamization on individuals, communities, and ultimately their nation or country. This is the main goal of Tarbiyah Movement. This pattern experienced a little change when the New Order ended. Liberalization and accommodation in a variety of socio-political expression, including of Islamic groups, opens wide opportunities for the movement of TM to formalize their activism. On March 29, 1998 or at the weakest time of the New Order regime, following the economic crises which is the main pillar of the regime, the network of Tarbiyah

${ }^{18}$ For this mission see R. William Liddle, "Skripturalisme Media Dakwah: Satu Bentuk Pemikiran dan Aksi Politik Islam Masa Orde Baru," Ulumul Quran 3, 4, (1993): pp. 5365. 
movement in public colleges, which were members of Forum Silaturrabmi Lembaga Dakwah Kampus (Gathering Forum of Campus Propagation Institute, FSLDK), instituted their movement to be Action Unit Indonesian Muslim Students (Indonesian Muslim Student Action Union, KAMMI). If the previous Tarbiyah Movement was more apolitical, through their KAMMI, they were very vocal to voice discontent against the New Order which almost collapsed. Metamorphosis of a cultural movement into a formal political movement became more evident when the movement of TM declared the establishment of the Justice Party (PK) on July 20, 1998 or exactly two months after the fall of the New Order.

Not only in politics, the formalization of Tarbiyah Movement activism also occurred in other fields, including education. In fact, as seen in the case of Jambi, which will be discussed in the following sections, in addition to formal activism through the establishment of educational institutions, they also take patterns of non-formal education in usrah, which is the root of this movement. Both formal and informal activism then goes hand in hand in the TM.

\section{Islamization from Within: Integrated Islamic School}

The dichotomy between the educational institutions of public education institutions on the one hand and religious education on the other, as written by Karel A. Steenbrink, has been ongoing since the Dutch colonial government introduced the school system for the purpose of producing colonial official candidates. Earlier, education was dominated by traditional institutions such as the recitation of the Qur'an and the Islamic boarding school that serves as a means of propaganda or dissemination of religious teachings. ${ }^{19}$

This dichotomy has been maintained even after Indonesia's independence. During the New Order government, the dichotomy increasingly found its existence through institutional standardization policy which was introduced in the Joint Decree of the Minister of Religion, Education and Culture Minister, and Minister of the Interior No. 6 of 1975. If public education takes the form of institutional and school system, religious education takes two forms, namely pesantren or Islamic boarding school which is the traditional Islamic educational institutions

${ }^{19}$ Steenbrink, Pesantren, Madrasah, Sekolah. 
and madrasah which is a more modern Islamic education institutions and parallel to the general school in many aspects. ${ }^{20}$ Nevertheless, with the "Islamic educational system ... adapt itself and fit into the general education system"21 either at Islamic (modern) boarding school as well as at the madrasah, general educational materials or subjects are also taught, which accounts for about 25 percent of the total hours of instruction. Meanwhile, to accommodate the needs of learners on religious instruction, in public schools are also taught subject matters of religion.

Such dichotomy in education was maintained properly during the authoritarian New Order, until the end of the 1980s the regime started to get closer to the Islamic groups. The climax took place when the Indonesian Muslim Intellectuals Association (ICMI) was established in September 1990 which was strongly supported by the New Order Government, chaired by Baharuddin Jusuf (B.J.) Habibie. This was followed by the departure of President Suharto to go for pilgrimage (Hajj) to the holy land a year later. Habibie closeness with President Soeharto, which existed since the appointment of technocrat graduates of German Minister for Research and Technology in 1978 to achieve industrialization and technologization mission heading to Indonesia's take-off, however, facilitates and eases the establishment of ICMI. ${ }^{22}$ Later on, the Soeharto's New Order even introduced a phrase that became Indonesians' vision of the 21 st century that wanted to produce this regime, which is the master of science and technology as well as having religious faith and piety or taqwa (IMTAQ). ${ }^{23}$

This vision makes a number of Muslim leaders and Muslim circles trying to find a role model of educational institution that is able to

\footnotetext{
${ }^{20}$ Ibid.

21 Ibid., p. 7.

22 Robert W. Hefner, "Islam, State, and Civil Society: ICMI and the Struggle for the Indonesian Middle Class," Indonesia, 56, (1993), 1-35; Mitsuo Nakamura, "The Emergence of Islamizing Middle Class and the Dialectics of Political Islam in the New Order of Indonesia: Preludes to Information of the ICMI," paper presented at Honolulu's seminar on "Islam and the Social Construction of Identities: Comparative Perspective on Southeast Asian Muslim”, August 1993.

${ }^{23}$ Sulfikar Amir, "Symbolic Power in a Technocratic Regime: The Reign of B.J. Habibie in New Order Indonesia," Sojourn: Journal of Social Issues in Southeast Asia, 22, 1, (2007): pp. 83-106.
} 
combine the knowledge of Islam on the one hand and the general sciences on the other in balance. The model that has been there, the madrassah, was regarded to have failed to carry out these tasks and could not compete with the public schooling system. They want the idealized educational institutions being able to produce graduates who are experts in the general area beyond the school and no less in the religious field of madrasah graduates even pesantren. It was after this that Islamic schools mushroomed everywhere in big cities like Al-Izhar Jakarta (founded by Bustanul Arifin in 1987), Bina Insani Bogor (Muchtar Mandala, 1990), Dwiwarna in Jakarta (Ginandjar Kartasasmita, 1992), Motahhari in Bandung (Jalaluddin Rakhmat, 1992), Lazuardi in Jakarta (Alwi Shihab and Haidar Bagir, 1994), Insan Cendekia Scholar in Jakarta (Habibie, 1996), and Madania in Jakarta (Nurcholish Madjid, 1996). ${ }^{24}$ Educational institutions they founded usually took the name "Islamic school" or "school plus". Nevertheless, it is consistent to take the name of "school", these institutions follow the schooling system that had been well known, but has added value ("plus") also in the field of Islam.

Apart from scholars like Nurcholish Madjid, Alwi Shihab, Jalaluddin Rakhmat, and Haidar Bagir, rich men such as Muchtar Mandala, as well as ministers or those who were close to the New Order regime (Habibie, Bustanul Arifin, and Ginandjar Kartasasmita), the TM which from the outset had an Islamist vision also offered the same thing. The earliest is Salman al-Farisi in Bandung, which served the educational level of childhood since 1989 and primary schools since 1991. Founded by TM activists in the city, Salman al-Farisi clearly took the name of Masjid Salman ITB, which during this became the center of their activism. Meanwhile, in Jakarta and surrounding towns, the Tarbiyah Movement activists established five schools at once that serves basic education or elementary: Nurul Fikri in Depok, al-Hikmah in South Jakarta, Iqro in Bekasi, Umm Quro in Bogor, al-Khayrot in East Jakarta. ${ }^{25}$

\footnotetext{
${ }^{24}$ This list is partly drawn from Hasan, "Islamizing Formal Education"; Hasan, "Education, Young Islamists". The founder and year of publication has been obtained from the website of each school.

25 "10 Tahun JSIT Indonesia Bangun Pendidikan Lewat SIT," Republika, 31 January 2014.
} 
Educational institutions belonging to the Tarbiyah Movement is called "integrated Islamic schools", intended as a school "free from secularism". ${ }^{26}$ By relying primarily on the thoughts of Hasan al-Banna, TM considers that the world has been beset by human-made ideological system, i.e. secularism. This system separates Islam or religion on the one side from the rest of others like the public life, education, economic, social, politics and culture on the other. As its major characteristics, Tarbiyah movement argues that Islam is al-Din or way of life in its total and comprehensive sense, encompassing all aspects of life. ${ }^{27}$ As an educational institution, integrated Islamic schools have a duty to teach Islam as a unified, whole, holistic, integral (shumüliyab), as opposed to secular, partial and dichotomous understanding of Islam (juziyah). ${ }^{28}$

The opportunity to establish Islamic educational institutions was open in the early 1990s but it later found its momentum after the fall of the New Order in 1998. The subsequent era of openness and liberal policies imposed makes a lot of aspirations that were previously under pressure mushroomed uncontrollably. Julie Chernov Hwang sees this phenomenon as "uncapped pot boiling" (removing the lid on a boiling pot). ${ }^{29}$ Tarbiyah movement which has an Islamist vision certainly did not waste the momentum for political change. After founding a political party and become the leader in the effort to formalization of Islamic law, this movement was benefitted from the openness of this era that makes it free to establish a lot of integrated Islamic schools in various regions in Indonesia. These schools provide education from kindergarten level to high school (SMA). In 2013, the school belonging to this Movement amounted to 1,926 units, consisting of 879 TKIT, 723 SDIT, 256 SMPIT, and 68 SMAIT. With such a large number, the brand integrated Islamic school became very popular in Indonesia. Some schools outside Tarbiyah even consciously also uses that name as an effort to obtain enthusiasts. As an effort to differentiate integrated Islamic schools belonging to the Tarbiyah Movement from those

\footnotetext{
26 Ibid.

${ }^{27}$ Muhtadi, Dilema PKS, p. 41.

28 Sukro Muhab, Standar Mutu Sekolah Islam Terpadu; Jaringan Sekolah Islam Terpadu (Jakarta: Jaringan Sekolah Islam Terpadu, 2010), p. 35.

${ }^{29}$ Hwang, Peaceful Islamist, p. 75.
} 
that are not, this movement further establishes the Integrated Islamic School Network (JSIT) in 2003. JSIT intended as an umbrella organization that serves to facilitate the development and empowerment of integrated Islamic schools that specifically owned by or affiliated with the Tarbiyah Movement. ${ }^{30}$

As in many other regions, the establishment of integrated Islamic schools by the TM in Jambi also cannot be separated from the context of political openness after the New Order. The firstly established school was SDIT Nurul Ilmi in 2002, located only about one kilometer from the central government of Jambi Province. Out of this school was subsequently born other integrated Islamic schools under this movement, including al-Siddiqi, an-Nahl Sprinkling of Faith, and Insan Madani. Schools that serve education from kindergarten to high school soon compete with the Islamic schools which had already existed, namely al-Falah under foundation based in Masjid al-Falah, a large mosque belonging to the Jambi provincial government, as well as alAzhar which is owned by the Diniyyah-based Foundation of Bungo. Later, with the great success achieved by integrated Islamic schools in Indonesia generally and in Jambi in particular, al-Azhar was also using that name, although it was not under JSIT or not part of the Tarbiyah movement.

In Jambi context, there are many explanations why the modern Islamic schools in general or integrated Islamic schools are especially preferred and get support from a lot of stakeholders. One among others is the character of Jambi Melayu who are mostly religious community, which is reflected in the traditional adage that "adat bersendi syara', syara' bersendi kitabullab" (tradition should be based on religious precepts and religious precepts should be based on God's book, i.e. the Qur'an). This means that all religious activities should be based on the Qur'an. These all requires educational institutions that teach religion. There is no guarantee that any particular religious teaching can be long-lasting unless with the supports of educational institutions. In the past, such tasks were fulfilled by traditional madrasah that served religious education in the afternoon, after children finished their morning general school. Nowadays, because of the policy of standardization of education introduced by the central government, traditional institu-

30 "10 Tahun JSIT". 
tional existence of madrasah increasingly is on the wane and many of them have been forcefully closed. The transition from traditional madrasah to integrated system also marks a change from an agrarian to urban society which in turn requires their presence at work for eight hours a day. The fear of losing most of their time in surveillance, their involvement in juvenile delinquency and drug addiction raises concerns among the parents for the safety of their kids. This moral panic makes the city's middle class Muslims choose to entrust their children to Islamic schools that offer a unified and full day schooling system even though they have to pay a lot more expensive than in the general schools. ${ }^{31}$ They are not concerned with this high cost because it is considered to be fair in comparison to the "quality" guarantee and the service gained by their children in the school. This is in addition to their thirst for religious education that can be fulfilled. At their offices, parents often proudly tell that their children had managed to memorize the Qur'an chapters 1-2, for instance. Optimism about the future of their children in integrated Islamic schools are also supported by the trend of "discriminatory" policy adopted by several public universities in Indonesia that exempted the entry test from those who can memorize parts or whole chapters of the Qur'an; some even give them schol$\operatorname{arship.~}^{32}$

In general, what is called by a combination of Islamic science and general science in an integrated Islamic schools belonging to the Tarbiyah Movement is simply a combination of two curricula. First, the curriculum as the school system in general is compiled by the Ministry of Education and Culture. Second, the curriculum set by JSIT contains Islamic materials such as literacy and memorization of the Qur'an, Hadith, jurisprudence, theology, religious practices and sirab nabawiyah (social history of the Prophet), as well as Arabic. In addition to the curriculum, coupled with student's self-development programs, including extra-curricular activities such as Scouts, sports and arts, Tahfiz

\footnotetext{
31 The Policy School Operational Assistance (BOS) established by the government to make public schools and private schools generally do not charge any fee from the students. Meanwhile, the initial cost of an integrated Islamic school in Jambi could reach Rp. 7 million and monthly fees or fees of Rp 580,000 per month in 2016.

32 For further discussion, see Marwazi and Husnul M. Abid, "Politics of Standardization: Traditional Madrasah, State Policies, and the Rise of Integrated Islamic School in Jambi" (forthcoming).
} 
(the Qur'an memorization), MABIT (building night of faith and piety), and tourist visits or riblah. Portions of curriculum is intended to form the high quality Muslim individuals idealized by Hasan al-Banna: physical strength, noble character, knowledgeable, creative and skilled work, straight faith, diligence in worship, emotionally stable, disciplined, being able to implement Islamic values, as well as beneficial for others. ${ }^{33}$ It is clear by now that the curriculum being taught in integrated Islamic schools is at the frontline of Islamizing individuals carried out by the Tarbiyah Movement starting from early childhood. By being part of integrated Islamic school, a student who is exposed into Islamic values will conduct the Islamization of family, community, and the rest of the world.

Although their main target is children who become their students, it is a mistaken to presume that integrated Islamic schools only target them. In integrated Islamic schools in Jambi, a parental or guardian meeting is held regularly in every two weeks. Meetings are usually held on a Saturdays or when the parents or guardians of the students have their working holidays, filled with religious lectures by preachers of TM. This meeting was a forum to convey Islamist ideas of TM. In addition to their children who deliver the movement ideals by their ways to their own family, the parents or family leaders are also approached directly through biweekly meetings under the Liqa' or halaqah programs. By doing so, the parents or guardians of students highly likely become interested and later join the Movement. In other words, through integrated Islamic school, Islamization efforts are continually being made from "within" by equipping students with Islamist ideals in order to deliver them further to their respective families at home.

\section{Islamization of Affairs: Islamic Spirituality in Public Schools}

Although the official Islamization and formal-institutionalization of Islam in integrated Islamic schools is capable of running as desired by the Tarbiyah movement, it is not the case in other schools that do not belong to them. In the other schools which are not under their control of course it is not free to play their role to transfer Islamist

${ }^{33}$ Editors of each integrated Islamic schools sometimes vary the order in formulating the ten characteristics of individuals which is the goal of education. On this purpose, compare with the idea of al-Banna as quoted by Mahmud, Ikhwanul Muslimin, pp. 1617. 
ideas to students. In addition to building a curriculum that cannot fully be intervened, the ownership of the school became the most powerful barrier. Although limited, the Tarbiyah movement can still take initiative to incorporate Islamist ideas into these schools. The main reason of course is due to the number of schools which is beyond the number of schools belonging to the Movement which is enormous, far beyond the integrated Islamic schools they have. Thus, the number of students accommodated in these schools are also reasonably far beyond their students. However, the potential is certainly dear to ignore. As a result, to schools outside of theirs, Tarbiyah movement is forced to apply the patterns of non-formal activism or Islamization from the outside.

As has been stated earlier, activism is not a formal institution or educational institution that is not theirs is nothing new for the Tarbiyah movement, but it has become a pattern of the movement which is embedded throughout since the beginning, especially when the New Order was strong and they had no other choice but to do the Islamization culturally from below. ${ }^{34} \mathrm{By}$ the time the pressure on Islamist groups loosens and gradually disappears with the fall of the authoritarian New Order regime, this movement has to change their strategy from preaching into structural-formal one. In fact they do not really leave patterns of old activism in the past that has proven to be capable of raising the movement. In schools outside of theirs, Tarbiyah movement continued the activity patterns of Islamist ideas by transferring them through what is known as Islamic spiritualism or Rohis (Kerohanian Islam). The only difference is, if in the past Rohis was purely formal and used cultural approach, in an era of freedom the movement seeks to serve itself as much as possible as an official students' extracurricular activities or incorporated itself in a formal curriculum..$^{35}$

Generally speaking, Rohis is a spiritual unit formed by a group of students who initially wish to study Islam together when general or secular schools did not provide any support or space for learning religious matters. The role of school alumni in the establishment and su-

\footnotetext{
34 Salim HS, Najib Kailani, and Nikmal Azekiyah, Politik Ruang Publik Sekolah, p. 29.

35 Generally, in Indonesia, curriculum consists of intra embodied curriculum in classroom teaching and extra-curricular or instructional supporting activities. If intra curriculum is a mandatory extracurricular is additional and optional. Nevertheless, extracurricular activities authorized and recognized as part of learning and supported by the school.
} 
pervision of this group is very central. Usually it is the alumni of the school studying at universities whom they met and joined the Tarbiyah movement, and then attempted to expand its footprint to school or their old alma mater. At their old schools they organized students who are from the younger levels to study Islam together under the unit called Rohis. Students in the middle of teenagers who are looking for identity met their alumni who have "succeeded" to find themselves in Islam, making this unit to expand in many public schools. The thirst for Islam minimally offered in public schools then is fulfilled and satisfied with the presence of Rohis.

Strategically, like other units of other extracurricular activities such as the Youth Red Cross, Boy Scouts, and Nature Lovers Group, Rohis is usually introduced before the orientation for new students at school. The initial introduction was intentionally followed by an offer in the form of a voluntary work of the activists, such as solving difficult tasks during orientation. The closeness and familiarity was built and later facilitate the activists of Rohis to offer activities on the sidelines of the schedule learning to new students. Being aware that such activities can increase their knowledge about Islam, plus support from teachers who see it as positive because the activities are concentrated in the school's mosque or prayer room, they are usually easily recruited. ${ }^{36}$

It is in this Rohis that students are accustomed to a position where men and women are separated, bijab is imposed upon all female students if they were in the same activity, avoiding contiguity between male-female, lower his gaze at the opposite sex, rejecting seclusion among teenagers, enforcing punctual five-daily prayers as well as commendable prayers such as Dhuha (morning prayers) during recess, targeting regular and continuous reading the Qur'an, and imposing Shar'i (large) veil for women. In some schools, whose Rohis has been strong enough and became the official unit in the school, it is usually also imposed for students to be mentored by more senior members, as a part of accelerated classes in Islamic instruction. ${ }^{37}$

In addition through the alumni who are members of the Tarbiyah Movement, Rohis connection with the movement is also established

\footnotetext{
${ }^{36}$ Salim HS, Najib Kailani, and Nikmal Azekiyah, Politik Ruang Publik Sekolah, pp. 3841.

${ }^{37}$ Ibid., p. 36.
} 
through unofficial organizations under Rohis umbrella. It is called unofficial because these organizations do not have formal relations with the management of Rohis structurally which is usually filled by internal members of the schools, by an Islamic teacher in the school as a coach. If there are officers from external management, they are usually the alumni on behalf of individual and not on behalf of the organization he or she is active in. However, in reality, in many cases it is the umbrella organizations that do not have a structural relationship that have a lot of initiative in driving Rohis and are more respected because they are more active than the official coaches of the school teachers.

In Jambi, there are at least two umbrella organizations, the Jambi Youth Care Forum (FPRJ) and Jambi City School Rohis Forum (FORSKA-J). Established in 2001, FPRJ is a wing organization that nurtures and cares Tarbiyah teens and specifically smaller Rohis in Jambi. ${ }^{38}$ The mission of this organization is as follows: (1) to foster a personality, faith and piety of Jambi younger generation, (2) to increase the intellectual potential, independence and leadership of the Jambi younger generation, (3) to turn on organizations of younger generation as a forum to develop the personal potential, and (4) to create an atmosphere with helpful activities and religious within schools, colleges and in the community. ${ }^{39}$ Calling himself the motto (Tagline) "laboratory for teenage characters", FPRJ views that the issue of twisted teens have become more and more complex. Teens are not only dealing with the issue of their development towards the adult phase, but they are also plagued by many things such as juvenile delinquency, use of illegal drugs, dating and even adultery, and poor moralities. The concern of FPRJ over the teen future makes it to carrying the main program which became the name of this organization, that is caring, that are intended as "assistance and guidance in forming a good personality to adolescents". Derivatives of the program are concerned in four activities of FPRJ, namely (1) coaching teenage characters, which is carried out intensively in groups, that are identical to the pattern of usrab ala Tarbiyah Movement, (2) fostering reading the Qur'an, (3) building faith night and piety or called MABIT, (4) training of mental development

38 "Visi dan Misi FPRJ", http://www.fprj.or.id/p/galeri-fpri.html. Accessed on 9 November 2016

${ }^{39}$ Ibid. 
through 3-4 day quarantine, (5) refreshing and (6) outbound activities. ${ }^{40}$

As part of adolescent care programs, FPRJ stimulates the establishment of Rohis in many schools in Jambi and supervises them. In 2013, the organization which had branches in many areas in Jambi Province establishes FORSKA-J, which was intended as a forum for inter-Rohis gathering in the city of Jambi. In 2016 at least 15 Rohis of SMA/SMK that has joined FORSKA-J. The administrators of FPRJ are members of the Tarbiyah Movement both located on campuses and off-campuses, with volunteer students from Rohis members; FORSKA-J management will be a member Rohis entirely with the chairman FPRJ as its coach. Being a subordinate organization and formation of FPRJ, FORSKA-J is actually an extension of FPRJ in order to effectively reach out to more schools. Therefore, programs or activities of these organizations are often side by side, which is usually provided by FPRJ, and FORSKA-J as the executor in the field.

In general, activities that are created by FPRJ or FORSKA-J can be grouped into two; namely routine and major events which involve many Rohis. For the former there are usually two organizations that create forums for teens or usrab coaching style as well as providing consultation for Tarbiyah movement or "mentoring" how to make Rohis as an active unit and get a lot of followers in schools. They also make themselves available at any time if asked to act in Rohis internal activities, such as a speaker or mentor in a group study. Meanwhile, by taking advantage of the school holidays, FPRJ and FORSKA-J make major activities which are attended by Rohis from many schools, two of which are Student Camp and FPRJ Award. Student Camp is a camp for a few days forging Rohis activists with various activities such as seminars, competitions, and hiking. Certainly in times of prayer, they do it in congregation, plus night prayers (Tahajud) and Dhuha prayers together and read the Qur'an. Student Camp is a combination of at least four FPRJ work programs, namely mental development through quarantine, mabit, refreshing, and outbound. Meanwhile, FPRJ Award is a tribute to the good administration activities of Rohis members. Nearly identical awarding popular in a film festival and a song or a beauty contest, FPRJ Awards are awarded based on certain categories

40 "Peduli Kepribadian Remaja", http://www.fpri.or.id/p/peduli-pribadi-remaja.html. 
such as best Rohis, favorite Rohis, most active mentoring, most active social media (Rohis), most active Rohis coach, most inspiring members of Rohis, most-active brother members of Rohis, most active sister members of Rohis, and most active new members of Rohis. ${ }^{41}$

Like Student Camp and FPRJ Awards, the activities of FORSKA and FPRJ-J, which involves Rohis, are packaged as something fun and enjoyable, and they are adjusted to what is being trend. For example, brand names of such activities are made in English which are more popular and trendy among teenagers instead of Arabic. Some of the activities are also explicitly taken from something that is popular, for example ASITERU or event friendship and New Rohis Members Meeting, which is taken from the song Aishiteru themed romance and popularized by bands of young Zivilia. They are also good at using the media which are being loved by teenagers as a means of communication such as Facebook, Twitter, Instagram, YouTube, movies, t-theme, etc. Every time they encounter characters like young people or teenagers, they always make use of it, among others, asking for autographs and expressions of support, which will be reproduced into a short film and uploaded to their social media accounts.

When they are in a public space which is a public school, with students who are mostly non-religious educational background, both Rohis and umbrella organizations FPRJ and FORSKA-J are very aware of their position. They also try to make any attempt to present Islam as an alternative in teenagers' life who generally likes fun or frivolous and become imitators of popular culture. Adjusting to the needs of adolescents, the Tarbiyah Movement through FPRJ and FORSKA-J and Rohis displays Islamist ideas wrapped in popular activities. The activists of Tarbiyah Movement are also aware that they are operating in the schools that is not theirs, and therefore choose the path of Islamization from outside to set up an organization like Rohis and FORSKA-J. As much as possible, their activities such as mentoring is done at school in the form of extracurricular activities, which are concentrated in small mosques belonging to schools, but it is not rare that Tarbiyah movement also takes students doing activities outside the school. Such activities prove that teenagers become important targets for the

41 See each category of the videos uploaded by fans page FPRJ Jambi di https://www.facebook.com/pg/fprikotajambi/videos/?ref=page internal accessed on 9 November 2016 
movement of Islamization of Tarbiyah movement, whose goal is to form and prepare individual Muslim teenagers before entering the gates of maturity which will have a larger task of Islamization of families and communities.

\section{From Mentoring to Graduation Regulation: Efforts in Higher Education}

As mentioned at the outset that at the beginning of the Tarbiyah movement are universities as a movement base. They set up small units called usrah for learning Islam and regular meetings in the forums called Liqa' or halaqah in campus mosques. This movement soon became preferred alternative for students' activism after they were barred from entering the practical political issues through the policy of NKK/BKK as mentioned above. Patterns of movement which were initially concentrated on a few large cities with big universities in Java such as Jakarta, Bandung and Yogyakarta, then spread to many colleges in other cities outside of Java, including in Jambi. As elsewhere, universities in Jambi which later became their base are state public universities, namely the University of Jambi, which is the largest university in terms of the number of departments and faculties as well as students in Jambi Province. ${ }^{42}$

Because the first movement pattern that is not formal and closed, it is difficult to get information on when was exactly the Tarbiyah movement existed for the first time at Jambi University. What is clear, is that in the 1980s this movement sufficiently rooted among students and used campus mosque, Masjid ar-Rahman, as the center of the movement. In April 1991, this movement even formalized activism into student activity units (UKM), which are named with the name of the mosque, namely UKM Rohis ar-Rhman. From here then the activists became leaders and administrators of organizations such as intra campus student senate and the executive body of students.

It is hard to argue against that the pattern of networking in the form of units of usrah as a meeting forum among mentors (as $m u$ rabbi/yah) and its members (mutarabbi/yah), and at a higher level where

42 Compare with M. Husnul Abid, "Kontestasi Kemelayuan: Islam Transnasional, Adat, dan Pencarian Identitas Melayu Jambi," in Mohammad Iqbal Ahnaf, Praktik Pengelolaan Keragaman di Indonesia: Kontestasi dan Koeksistensi (Yogyakarta: Center for Religious and Cross-Cultural Studies, 2015), pp. 194.195. 
fellow mentors gathered to learn from more senior mentors, has been responsible for raising the movement of Tarbiyah at Jambi University. Not only learning religious matters, mentors of usrah also provide guidance to mutarabbi/yah which is at the same time also a junior who studies how to study well in college and how they solve the problems faced by students. The pattern is then made many students of Tarbiyah movement gain good academic performance so that they are favored by their lecturers. In return, this movement has increasingly got a place in the hearts of faculty and university leaders. Not a few, even members of the Tarbiyah Movement graduating with a good performance and then have been recruited as lecturers at Jambi University. Together with the alumni who work off campus, whose relationship with them continues to be properly maintained, the lecturers, who are not the least of which an officer or leader at the university, then help the students who are their juniors to develop the Tarbiyah movement in the campus. Within a reasonable time, it makes the Tarbiyah movement very solid and strong rooted at Jambi University not only among students but also among faculty and university leaders. ${ }^{43}$ This explains why many agenda of this movement later, as will be discussed below, get the ease and success when it realized in the form of programs and activities including that go beyond proper role of students of general colleges.

As the main wing organization of Tarbiyah Movement located on campus and received support from the University of Jambi in the form of units of student activities, Rohis UKM of ar-Rahman became a leader in the transfer of Islamist ideas of the movement to the academic community, especially students. Engaged in "moral development, fraternity, scientific and socio-political community", UKM Rohis arRahman had the following goals (1) to optimize, actualize, and empower Muslim students at Jambi University through various activities of spirituality as well as in all functions of the life of the student and (2) to develop and improve brotherhood of Islam towards unity and integration through the coordination of Muslim students of Jambi University. In order to realize these objectives, the general efforts or programs that promoted UKM Rohis ar-Rahman is (1) to guide the campus dakwah activists, (2) to establish a climate conducive to the devel-

${ }^{43}$ Abid, “Kontestasi Kemelayuan”, pp. 194-195. 
opment of Islamic values by implementing the symbols of Islam consistently, (3) to build Islamic brotherhood through the process of knowing each other, understand and help each other as well as the competitiveness of prioritizing each other in achieving the goals of propaganda, and (4) to build awareness, responsibility of society through empowerment of the campus community in order to contribute to real life for the betterment of society. ${ }^{44}$

While UKM Rohis ar-Rahman is a campus propaganda institution (LDK), which is located at the university level, at the faculty level they make branches in the form of institute of faculty propaganda (LDF). Different from the university level which uses the name refers to an Islamic organizations, even identifying themselves as the Islamic spirituality or Rohis, most LDF use the name and form a study group and creativity based on a subject or department. With more open impression, this naming seems to be a strategy to obtain broader followers, because they are seen not only to care about Islam, but also in regards to creativity and knowledge, which could be a student activism to succeed academically. The names include the Forum of Muslim Scholars in the Faculty of Law, Circles of Islamic Scientists or LSI (Faculty of Science and Technology), the Forum Insan Scholar (FIC) as-Siyasah (Faculty of Social and Political Sciences), Scientific Forum of Muslim Students or FIHMI (Faculty of Sport Science), and the Forum of Islamic Studies or FSI (the Faculty of Education). ${ }^{45}$ Furthermore, every LDF in all faculties, which are coordinated by their higher level of organization, UKM Rohis ar-Rahman, collaborates together in making programs and activities into a container of what they call the Islamic dakwah to students.

One of the propaganda that becomes their main activity is the assistance or mentoring in the study of Islamic matters. Earlier, particularly during Soeharto Era this activity was informal in nature and closed from outside community, along with the increasing acceptance of Islamic activism on campus as well as the opening door for freedom and political climate in Indonesia, mentoring has been programmed into university policy. On the ground of mentoring that will be able to

\footnotetext{
44 "Profile UKM Rohis Ar-Rahman Unja".

${ }^{45}$ For more details on LDF-LDF that exist in all campuses, see "Profil UKM Rohis Ar-Rahman Unja”.
} 
accelerate learning, especially for students of general (non religious senior high schools) background who have difficulty in Islamic lectures, while the subjects are only weighs two credits because it is given once in a week for two-hour instruction, Tarbiyah movement managed to convince the leadership of the University of Jambi to make mentoring become an integral part of the lectures and legalize it in the form of Spiritual Guidance of Islamic Students (Promis). At the beginning of every term, students who take the course for first semester of Islam are gathered in the auditorium of the university to be briefed by professors from Islamic activist background and divided into small groups called usrah. Containing around ten students for each group, they then learn together about basic teachings of Islam such as purification, prayer, reading the Qur'an, and learning the history of the Prophet, supervised and accompanied by a mentor (murabbi/yah). The mentor is a senior of those who have passed the course Islam and have passed certain tests to be a companion. Under the coordination of UKM Rohis arRahman, they usually are senior members of the movement and are still students. Here, then the Tarbiyah movement through UKM Rohis ar-Rahman freely plays its role in the transfer of Islamist ideas. Because Promis is mandatory and mentors also helped give a final assessment, each student had to have passed this process and stick with it if one does not want to fail the course. ${ }^{46}$

By the time the course ended, the students are asked to gather again. This time they are given guidance and encouragement to participate in advanced mentoring. Despite the continued mentoring is not required as before, not a few students who have already familiar with a group of friends and murabbi/yah in a mentoring them decided to join the advanced mentoring. In advanced mentoring which is stratified, they then got the higher materials, not only about the teachings of Islam, but also about global politics and its impact on the Islamic world, such as the Palestinian-Israeli issue. They are also guided to study the minutes of movement as well as the thoughts of the ideologues of transnational Islamic movements, particularly the Muslim Brotherhood of Egypt, which is a lot of influence and inspire the Tarbiyah movement in Indonesia. In addition to the top-level students who are members of the movement, murabbi/yah continued mentoring those whose

${ }^{46}$ Interview with AH, November 2012. 
background were previously not part of the University of Jambi. ${ }^{47}$ If the previous mentoring can be called as the introduction phase, by joining the continued mentoring at the upper levels, these students have now become an integral part of the Tarbiyah movement. ${ }^{48}$

Students who originally entered through Promis of Tarbiyah Movement and continued with advanced mentoring, they then manage many organizations that were formed by Tarbiyah movement on campuses. They are active and take charge in the LDF or LDK and coordinate study groups routinely centered on prayer room and the campus mosque, both closed to their circles and are open to the public. They also enter into campus activities and color other UKM at Jambi University. Members who have skills in the leadership of the movement subsequently are sent by Tarbiyah movement to occupy positions of intra campus organizational leaders from the level of department, faculty, up to university (such as vice rector). All the exponents of the movement that has entered into many elements of the campus became effective machines that move together to carry out the work of Islamization among academics in and outside Jambi University. ${ }^{49}$

One of the most recent developments of activism of Tarbiyah movement at Jambi University in the mid-2015 is that when they managed to achieve the religious regulations which established requirements for students who will graduate and attend graduation ceremony, the Rector Decree No. 467 / UN21 / KM / 2015. Although in it also contains provisions similar to other faiths by adjusting the conditions, the primary objective of this regulation is clear for Muslim students. Muslim students, if they want to pass, they have to have finished read-

\footnotetext{
47 Interview with AH, November 2012. Compare with Abid, "Kontestasi Kemelayuan", pp. 195-196.

48 According to Hasan al-Banna, there are three steps (marbalab) in Tarbiyah movement, (1) getting to know the object of dakwah (ta'rif), (2) coaching new cadres (takwin), (3) actualizing dakwah activities (tanfiv). See al-Banna, Himpunan Risalah, 12-13. In ta'rif stage, an activist of Tarbiyah Movement should hide or keep in secret his or her proselytizing or movement. Mushthafa Masyhur, Amal Jama'i: Gerakan Bersama, trans. (np: Pustaka Indonesia, no date), 9-12.

${ }^{49}$ Interview with AH, November 2012.
} 
ing the Qur'an as a whole, from chapter 1 to chapter 30 with certificate of completion in reading the Qur'an. ${ }^{50}$

For those who have a tradition of chanting the Qur'an regularly such as students who have taken advanced mentoring and become members of the Tarbiyah Movement, because it has been so emphasized, that provision might not a big deal at all. However, for other students who have not had such a tradition it is a big problem. Although it has been accelerated in mentoring at Promis, their educational background in general public schools with no tradition of strict recitation of the Qur'an will feel difficult in meeting this requirement. ${ }^{51}$ It is exactly here the Tarbyah Movement plays its crucial role. In addition to become listeners to the students who will graduate, they were appointed to be a mentor for students whose reading the Qur'an was below the standard. By becoming a mentor, they have a second chance to re-recruit students into the Tarbiyah movement. The Tarbiyah Movement was benefitted most by this regulation. This regulation, in turn, becomes a sort of new rules that force students to remain in their mentoring after completing Promis and Islamic lectures. ${ }^{52}$

Various efforts made by Tarbiyah Movement in colleges as has been elaborated above, as it is also done in public schools outside their own, show that this movement continues to play strategic role in the Islamization of individuals and society. Although many educational institutions do not belong to the Tarbiyah movement, it did not impede their efforts in the Islamization program. Through the establishment of many organizations who move in those campuses, they then go inside and affect learning. Such efforts can work and are usually effective. They even become dominant among many organizations or other religious movements, including decade-older student organization such as PMII (Pergerakan Mahasiswa Islam Indonesia, the Movement of Muslim Students of Indonesia) and HMI (Himpunan Mahasiswa Indonesia, the Association of Indonesian Muslim Students).

\footnotetext{
50 "Jambi University Imposes Religious Requirements", Jakarta Post, 4 July 2015; "Universitas Jambi Wajibkan Khatam Alquran sebagai Syarat Wisuda", (Jambi Universit requires students to Khatam the Qur'an as a graduation requirement) Republika, 3 July 2015.

51 Interview with An, 3 December 2016.

52 Interview with and discussion with Em, 5 February 2017.
} 


\section{Conclusion}

As this paper has demonstrated, Tarbiyah movement has set a long promising, convincing, and strong political agenda through various efforts and steps through education, particularly after they have failed at the State level. This paper has elaborated that education seems to be the last resort upon which the Tarbiyah Movement has rested its ideals and programs. One of the ways of so doing is by establishing educational institutions of their own. Another way is by interfering into public or secular educational institutions particularly state education. This means that while working with more definite strategy, Tarbiyah movement also makes any effort necessary for their short term target. The third way is by creating networks among alumni of both senior high schools and universities.

Tarbyiah movement is very talented in making and maintaining networks. Various ways and efforts are created in order to ensure the continuation of the networks. The final and most strategic way is by electing or appointing their alumni to be leaders of important position in those schools or universities who receive payback by providing access and facilities for Tarbiyah's activities and programs. By building such strong attachment and networks, the future of political gain for Tarbiyah movement will possibly contribute to the future of Indonesian politics. It is only a matter of time that the well trained political leaders of this movement will change the future of political Islam in this country.]

\section{References}

\section{Books and Articles}

"10 Tahun JSIT Indonesia Bangun Pendidikan Lewat SIT." Republika, 31 January 2014.

"Jambi University Imposes Religious Requirements." Jakarta Post, 4 July 2015.

"Universitas Jambi Wajibkan Khatam Alquran sebagai Syarat Wisuda." Republika, 3 July 2015.

Abid, M. Husnul. "Kontestasi Kemelayuan: Islam Transnasional, Adat, dan Pencarian Identitas Melayu Jambi." Mohammad Iqbal Ahnaf. Praktik Pengelolaan Keragaman di Indonesia: Kontestasi dan 
Koeksistensi. Yogyakarta: Center for Religious and Cross-Cultural Studies, 2015.

al-Banna, Hasan. Himpunan Risalah. trans. np, nd.

al-Qardhawy, Yusuf. Pendidikan Islam dan Madrasah Hasan al-Banna, trans. Jakarta: np, 1980.

Amir, Sulfikar. "Symbolic Power in a Technocratic Regime: The Reign of B.J. Habibie in New Order Indonesia." Sojourn: Journal of Social Issues in Southeast Asia, 22, 1, (2007).

Asyari, Suaidi and M. Husnul Abid. "Expanding the Indonesian Tarbiyah Movement through Ta'āruf and Marriage." al-Jämi'ah: Journal of Islamic Studies, 54, 2, (2016): pp. 337-368.

Damanik, Ali Said. Fenomena Partai Keadilan: Transformasi 20 Tabun Gerakan Tarbiyah di Indonesia. Jakarta: Teraju, 2001.

Feisal, Jusuf Amir. Reorientasi Pendidikan Islam. Jakarta: Gema Insani Press, 1995.

Furkon, Aay Muhammad. Partai Keadilan Sejabtera: Ideologi dan Praksis Politik Kaum Muda Muslim Indonesia Kontemporer. Jakarta: Teraju, 2004.

Gaffar, Afan. "Politik Akomodasi: Islam dan Negara di Indonesia." M. Imam Aziz (ed.). Agama, Demokrasi dan Keadilan. Jakarta: Gramedia Pustaka Utama, 1993.

Hasan, Noorhaidi. "Education, Young Islamists and Integrated Islamic Schools in Indonesia." Studia Islamika, 19, 1 (2012).

Hasan, Noorhaidi. "Islamizing Formal Education: Integrated Islamic School and a New Trend in Formal Education Institution in Indonesia." RSIS Working Paper, No. 172. Singapore: Nanyang Technological University, 2009.

Hefner, Robert W. "Islam, State, and Civil Society: ICMI and the Struggle for the Indonesian Middle Class." Indonesia, 56, (1993): pp. 1-35.

Hwang, Julie Chernov. Peaceful Islamist Mobilization in the Muslim World: What Went Right. New York: Palgrave Macmillan, 2009.

Muhab, Sukro. Standar Mutu Sekolab Islam Terpadu; Jaringan Sekolah Islam Terpadu. Jakarta: Jaringan Sekolah Islam Terpadu, 2010. 
Latif, Yudi. "The Rupture of Young Muslim Intelligentsia in the Modernization of Indonesia." Studia Islamika, 12, 3, (2005): pp. 390401.

Liddle, R. William. "Skripturalisme Media Dakwah: Satu Bentuk Pemikiran dan Aksi Politik Islam Masa Orde Baru." Ulumul Quran 3, 4, (1993): pp. 53-65.

Machmudi, Yon. Islamising Indonesia: The Rise of Jemaah Tarbiyah and the Prosperous Justice Party (PKS). Canberra: ANU E Press, 2008.

- Partai Keadilan Sejabtera: Wajah Baru Islam Politik Indonesia. Bandung: Harakatuna Publishing, 2005.

Mahmud, Ali Abdul Halim. Ikhwanul Muslimin: Konsep Gerakan Terpadu, Vol. 2, trans. Masykur Halim and Ubaidillah. Jakarta: Gema Insani Press, 1997.

Maksum. Madrasab: Sejarah dan Perkembangannya. Jakarta: Logos, 1999.

Marwazi and M. Husnul Abid. "Politics of Standardization: Traditional Madrasah, State Policies, and the Rise of Integrated Islamic School in Jambi." (forthcoming).

Masyhur, Mushthaf. Amal Jama'i: Gerakan Bersama. trans. np: Pustaka Indonesia, nd.

Muhtadi, Burhanuddin. Dilema PKS: Suara dan Syariah. Jakarta: Kepustakaan Populer Gramedia, 2012.

Nakamura, Mitsuo. "The Emergence of Islamizing Middle Class and the Dialectics of Political Islam in the New Order of Indonesia: Preludes to Information's of the ICMI." paper presented at Honolulu's seminar on "Islam and the Social Construction of Identities: Comparative Perspective on Southeast Asian Muslim", August 1993.

Rahmat, M. Imdadun. Ideologi Politik PKS: Dari Masjid Kampus ke Gedung Parlemen. Yogyakarta: LKiS, 2008.

Salim, Hairus HS., Najib Kailani, and Nikmal Azekiyah, Politik Ruang Publik Sekolab: Negosiasi dan Resistensi di SMUN di Yogyakarta. Yogyakarta: Center for Religious and Cross-Cultural Studies, 2011. 
Sirozi, Muhammad. Politik Kebijakan Pendidikan di Indonesia: Peran Tokohtokoh Islam dalam Penyusunan UU No. 2/1989. Leiden-Jakarta: INIS, 2004.

Steenbrink, Karel A. Pesantren, Madrasah, Sekolab: Pendidikan Islam dalam Kurun Moderen. Jakarta: LP3ES, 1994.

Susetyo, Benny. Politik Pendidikan Penguasa. Yogyakarta: LKiS, 2005.

Tim Penulis Modul Lembaga Kajian Manhaj Tarbiyah (LKMT). Modul Tarbiyah Islamiyah untuk Murobbi: Marbalah Tambidi, Vol. 1 and 2. Jakarta: Robbani Press.

Yunus, Mahmud. Sejarah Pendidikan Islam di Indonesia. Jakarta: Mutiara, 1979.

\section{Internet Sources:}

"Peduli Kepribadian Remaja", http://www.fprj.or.id/p/peduli-pribadi-remaja.html.

"Profil UKM Rohis Ar-Rahman Unja", http://ldkarrahman.or.id/2016/10/06/profil-ukm-rohis-ar-rahman-unja/.

"Visi dan Misi FPRJ", http://www.fprj.or.id/p/galeri-fprj.html.

\section{Interview:}

AH, November 2012.

Em, 5 February 2017.

An, 3 December 2016. 